\title{
SMART VILLAGE DEVELOPMENT PRINCIPLES AND DRIVING FORCES: THE CASE OF LITHUANIA
}

Vilma Atkočiūniené ${ }^{1}$, Gintarè Vaznonienè ${ }^{2}$

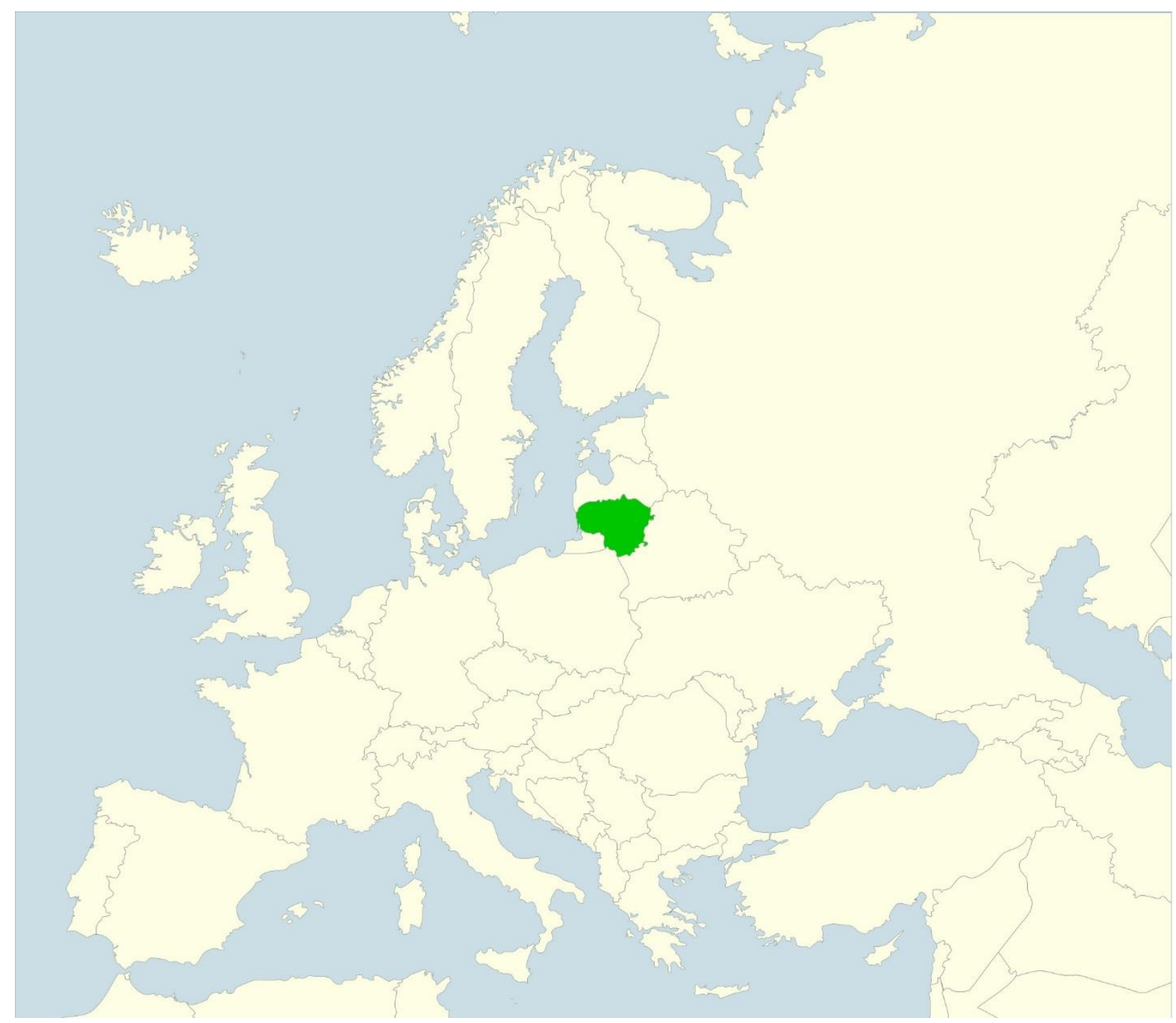

${ }^{1}$ Prof. dr. Vilma Atkočiūnienè, Vytautas Magnus University, Kaunas, Lithuania, ORCID: 0000-0001-6908-9339, e-mail: vilma.atkociuniene@vdu.It

${ }^{2}$ Assoc. prof. dr. Gintarè Vaznonienè, Vytautas Magnus University, Kaunas, Lithuania, ORCID: 0000-0001-9583-112X, e-mail: gintare.vaznoniene@vdu.It 


\begin{abstract}
Traditional and emerging interest networks supported by the advancement of digital and telecommunication technologies, the growing use of bioenergy and the ability to take advantage of knowledge beneficial for local populations and business development promote strategic breakthroughs of rural communities. The paper focuses on the problem of the smart village development with respect to a sustainable rural regional development. The aim of the research is to identify the preconditions for rural area progress and smart rural villages driving forces in Lithuania. The research object concerns the principles and driving forces of the development of smart villages. The research methods inter alia included analysis, systematization, and comparison of scientific literature, documents, and good practice examples. Analysis of the experiences of villages and local/international organizations and research into the best practices helped to identify the drivers and the key principles of the smart village development. The case study revealed that three out of five selected pilot rural areas of Lithuania have an innovative potential with some of the smart village principles adopted. The main constraints identified by the study were related to the lack of technological, digital or energy efficiency innovation and human resources in rural areas.
\end{abstract}

Key words: smart village, driving forces of smart village development, rural regional development

Santrauka: Straipsnyje daugiausia dėmesio skiriama pažangių kaimų vystymo problemai, susijusiai su tvaria kaimo plètra. Tyrimo tikslas - identifikuoti prielaidas kaimo vietovių pažangai ir pažangaus kaimo vystymosi varomąsias jègas. Tyrimo objektas pažangaus kaimo vystymosi principai ir varomosios jégos. Atliekant tyrimą taikyti mokslinès literatūros, dokumentų, gerosios praktikos pavyzdžių analizès, sisteminimo, sugretinimo ir kiti metodai. Teoriškai nustatytos ir pilotinèms vietovèms tirti pagrịstos pažangaus kaimo vystymosi varomosios jègos kaip skaitmeninès ir kitos atviros inovacijoms platformos; dalijimosi ekonomika; žiedinè ekonomika; bioištekliais (atsinaujinančiais ištekliais) pagrįsta ekonomika; atsinaujinanti energija; kaimo turizmas, apimantis ekologinį, sveikatai palanku maistą ir poilsị, rekreacinį turizmą; socialinès inovacijos kaimo paslaugu ir verslumo srityje; itraukios socialinès infrastruktūros, partnerystès organizacinio mechanizmo kūrimas ir diegimas. Vietos ir tarptautinių organizacijų patirtis, gerosios praktikos pavyzdžiai padėjo suvokti pažangaus kaimo vystymosi varomąsias jègas ir pagrindinius principus. Atvejo analizè atskleidè, kad trys iš penkių pasirinktų pilotinių kaimų turẻjo potencialą naujovèms, iš dallies taikè sumanaus kaimo vystymo principus. Pagrindiniai apribojimai buvo technologinių, skaitmeninių, bioenergijos naujovių diegimas ir žmogiškujų ištekliụ trūkumas.

Raktiniai žodžiai: pažangūs kaimai, pažangaus kaimo vystymosi varomosios jègos, kaimo regioninè plètra

\title{
1. Introduction
}

The society of the late 2010s has been undergoing a cultural and technological shift, which has been redefining the relationships among people, new technologies, science, and creativity. The Smart Village movement, which has lately been gathering pace in the European Union (EU) states and other countries, addresses rural communities that undertake an innovative approach in unlocking the potential of the rural area development and set clear directions of the development (White Paper, 2017). Rural communities are assisted in achieving a strategic breakthrough through conventional and new stakeholder networks supported by the progress of the digital and telecommunication technologies, the growing use of bioenergy and the ability to use available knowledge for the benefit of local populations and business development. Communities that create viable villages are those that keep learning to perceive, to use 
the advantages of rural areas and to promote the values of living in the countryside. Digital technologies and innovations help to deliver a better quality of life, better public services, and a more efficient and economic use of the local resources. Links between traditions and latest technologies enable the creation of new value chains in rural areas. This opens new opportunities for rural development as the "largest quantity at the lowest price" approach is being forced out by food quality, consumer health and animal welfare, biodiversity, the value of rural landscape and environmental resources, preservation of family farms, local species, and rural traditions, which are currently viewed as priorities by the European society. The goal of the stakeholders who participate in the development of the local economy is to explore ways of enhancing production and consumption of local produce through the creation of positive relationships between the consumers and farmers, consumers and craftsmen, and supporting sustainable rural development, rather than further development of low-cost local produce (Guidance for Local Actors..., 2018).

The European Commission (Communication from the Commission..., 2017) is committed to support the creation and promotion of value chains for local produce and to promote and support the Smart Village movement. However, the Smart Village movement is not a cure-all for every challenge faced by rural areas. Rather, it is a call by the European Commission for both the governments and local communities to look for territorially wise decisions meeting the needs of local populations and representing the development potential, as well as a call for local communities to develop their long-term survival strategies based on scientific and technological innovations.

The research object, which is the principles and driving forces of the smart village development, has deeply not been by scientists. Researchers Marsden and Sonnino (2008), Holmes (2017) are seeking to design a Smart Village model, to identify the key characteristics of a smart village and the development tools and methods. In 2014-2017, Holmes (2017) identified the basic conditions for the provision of energy services to villages to ensure livelihood opportunities, provision of services (healthcare, education, clean water, and sanitation) and empowerment embodied in the Smart Villages concept. The extent to which innovation processes are place-specific and why they are place-specific has been the driving force of many studies (Edwards, Haines, 2007; Glasmeier, Christopherson, 2015). Naldi et al. (2015), which conceptually analyse and bring together ideas underlying the logic behind the policies for smart growth by focusing on smart growth from the perspective of rural regions. The scientists present indicators of the smart rural development and analyse their relevance in future empirical studies. Best practice examples and case studies, assessment, and sociological surveys are the most commonly used methods in investigation of the smart village development and the new content and forms of knowledge and learning (Somwanshi et al., 2016; Orbàn, 2017; Sumane et al., 2017). Furthermore, scientists point out that the smart village development is not self-evolving; it requires new organizational structures. The focus is placed on open platforms, Living Labs (Guzmán et al., 2013; Robledo et al., 2014; Callaghan, Herselman, 2015; Tirziu, Vrabie, 2017), the LEADER programme, and local action groups (Chevalier et al., 2014).

Lithuanian researchers have increasingly been focusing on the environment and the opportunities for rural area development. Vveinhardt (2011), Šimanskienè and Sandu (2013) noted that much of the success of an organization depends on and appropriate and well-designed organizational culture, which is one of the most important issues in the rural area organizational culture management model (Slivinskienè, 2018) and the life of an organization. Baležentis (2011) used the expert evaluation method to identify the opportunities for a sustainable development of Lithuanian rural areas. In terms of the sustainable development, homesteads meet the economic and environmental criteria most closely, whereas small towns lead in terms of meeting the social criteria. Settlements, which hold the second position in terms of three sustainable development criteria following the decline of the social infrastructure have preserved one of the advantages, the neighbourhood relationships. In their analysis of the ecovillage case, Vidickiene et al. (2016) looked for an ideal model of a post-industrial settlement. The researchers found that natural environment is formed according to certain pre-established standards and economic activities are performed in line with strict principles of environmental performance, biodiversity enhancement and permaculture without harming the environment and future generations. Stareike (2017) 
analysed one of the measures for rural area progress. She defined and studied the functioning of the partnership organisational mechanism in Lithuanian local action groups and identified the key patterns of its operation. According to her findings, particular emphasis is put on eco-technological solutions.

The integrated goal of the post-2020 Common Agricultural Policy is to promote knowledge, innovations, and digitalisation in agriculture and rural areas, and the results and performance indicators, rather than the rules and compliance with them (Communication from the Commission..., 2017). This has been prompting the researchers and policy makers to explore new instruments ensuring sustainable agricultural and rural development. The research has been conducted to answer the question as to which drivers are behind the development of smart villages.

The aim of the research is to identify the preconditions for the progress of rural areas and the driving forces of the smart village development in Lithuania. The research used the methods of analysis of scientific literature, documents, good practice examples, systematization, parallel method, etc. The conceptual basis of the article consists of the theories of sustainable development, stakeholders' activism, and social partnership.

The article has several parts. Part 2 discloses the theoretical background of the smart village development with a focus on the characteristic criteria of a smart village, Part 3 describes the research methodology and Part 4 explores the results of the empirical research based on the analysis of practical and case studies. Finally, the paper offers some conclusions.

\section{Research methodology}

The research used the mix-method approach as it enables the integration of several methods: scientific literature analysis and synthesis, document content analysis, analysis of good practice examples, parallel method, in-depth analysis, and analysis of internet sources. The above research methods were applied in conceptualizing the sources, driving forces, preconditions and limitations of the smart village development. This was realised following some logical steps (see Figure 1).

Following Figure 1, the empirical insights of the research are related to identifying criteria that may be used to evaluate smart villages in Lithuania. According to the analysis of practical studies dealing with the smart village development, the case study method was chosen as the main research method combined with internet link analysis. This method was used to investigate selected villages (information was gathered from local newspapers, community eldership sites, tourism centres, etc.) that allow a comparison of the smart village criteria in those villages. The criteria for choosing particular pilot villages included the following:

1. The villages have to be known at the national and regional levels.

2. Activities and changes in the pilot villages are of interest to persons and institutions, including others than local mass media.

3. The villages promote inclusion of different social groups into different activities despite their status (human empowerment).

4. Three out of five villages are known as small capitals of culture in Lithuania.

5. The villages have adopted co-creation processes: local organizations work to integrate and transform resources and competences. 


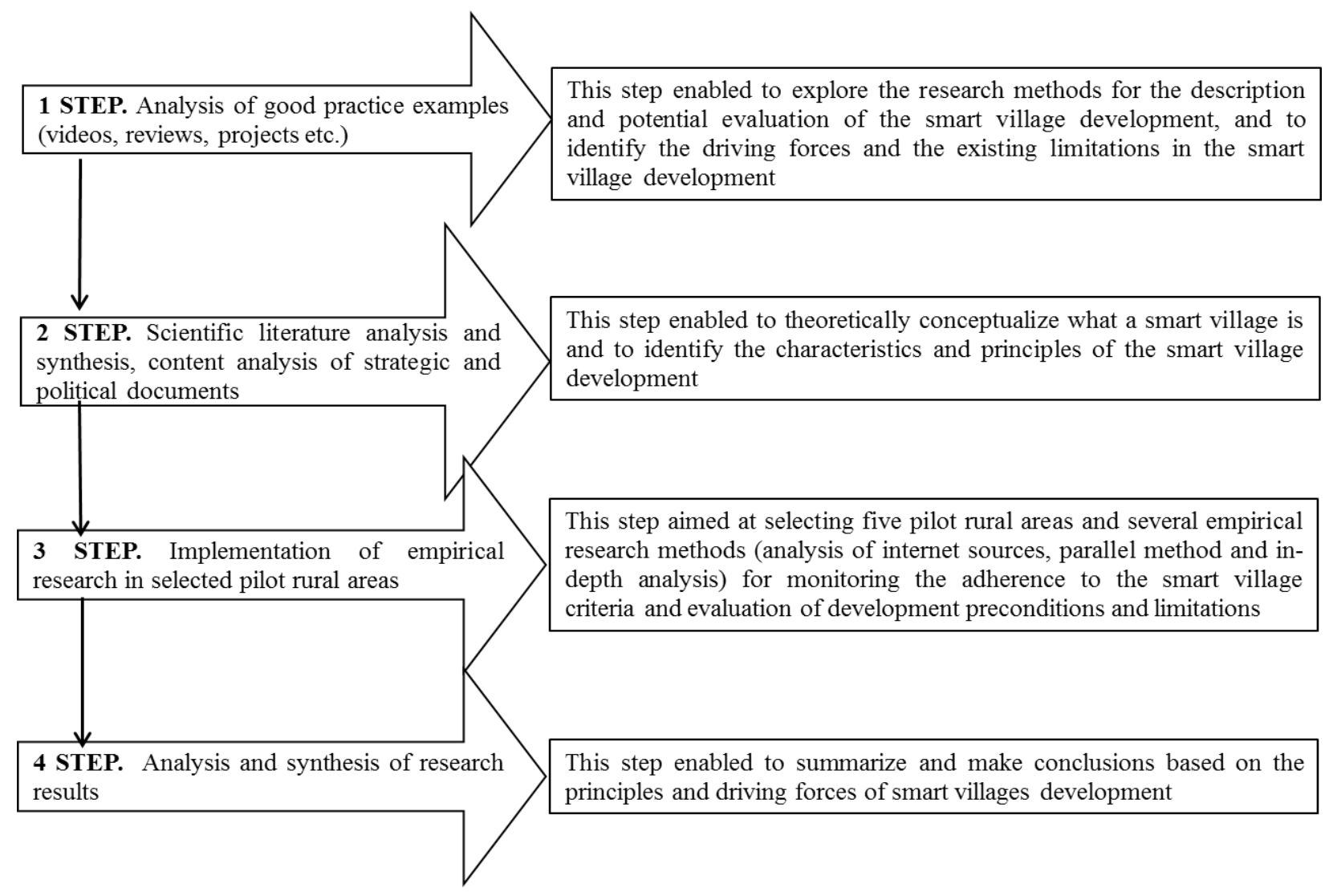

Fig 1. Empirical research preparation and implementation steps.

The theoretical approach describing the criteria that characterize smart villages enabled the researchers to see how different criteria can be applied to the selected pilot villages in Lithuania (Fig. 2).

However, based on the Internet sources related to the pilot villages, the actual picture disclosed that not all criteria may be appropriate for the selected pilot villages.

The main limitations of the research include: 1) the smart village approach was applied only to several villages of Lithuania, mostly representing the northern and western parts of Lithuania (Samogitia ethnographical region) and located at different distances from big cities (Kražiai, Kelmè district municipality; Naisiai, Šiauliai district municipality; Smalininkai, Jurbarkas district municipality; Ukrinai, Mažeikiai district municipality; Vatušiai, Rietavas municipality), which were chosen as pilot areas to see how smart village principles and elements actually work; 2) the choice of villages is limited due to the lack of information about local areas on the Internet and the data referring to certain challenges in the area are quite abstract or fragmented. 


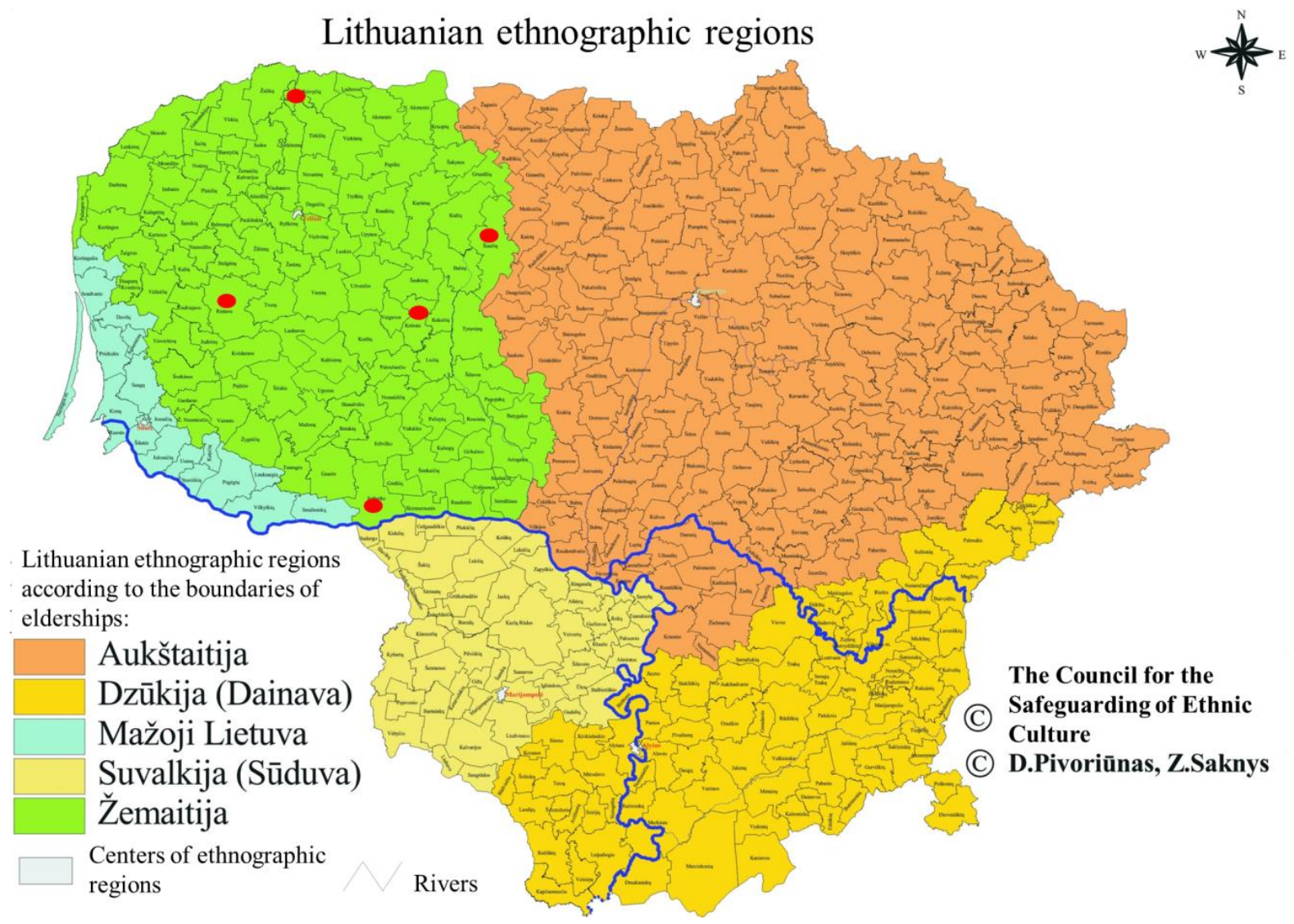

Fig 2. Lithuanian ethnographic regions according to the boundaries of elderships. Source: Ethnographic regions. Lithuanian National Heritage. Available at: https://www.tautinispaveldas.It/static/img/etnografiniai5e1c.jpg

Note: red dots show the place of selected villages in particular eldership

\section{Political and theoretical background}

\subsection{Preconditions for rural area progress development}

The place-based approach instead of a focus on sectors and a focus on investment instead of subsidies, put forward the concept of territorial dynamics to denote a set of specific regional and local factors, structures and tendencies developed in the "New Rural Paradigm" (OECD, 2006). The "2030 Agenda for Sustainable Development" provides for the establishment of smart villages (United Nations, 2015) and sets out 17 sustainable development goals with 169 associated targets.

The rural area development principles have been put down in Cork Declaration "A Living Countryside", defining the integrated development of rural areas as unique social, economic and cultural infrastructures and the objective "to make rural areas more attractive for people to live and work in and become centres of a more meaningful life for a growing diversity of people of all age" (Cork Declaration, 1996). Two decades later, changing social, economic, and environmental situation, including that in the rural areas, led to a revision of the policy areas defined in 1996. Cork 2.0 Declaration "A Better Life in Rural Areas" identifies ten policy areas (Cork Declaration, 2016) and emphasizes that the rural and agricultural policy in the EU should be innovative, integrated, and inclusive (Table 1). 
Tab 1. Comparison of the main provisions on the development of smart rural areas in Cork 1.0 and Cork 2.0 Declarations

\section{Cork 1.0 Declaration - A Living Countryside (1996)* \\ 1. Rural Preference. Putting sustainable rural development at the top of the EU agenda. Reversing rural out-migration, combating poverty, stimulating employment and equality of opportunity, responding to growing requests for quality, health, safety, personal development and leisure, and improving rural well-being. \\ 2. Integrated Approach. Multi-disciplinary rural development policy, multi-sectoral application, with a clear territorial dimension. \\ 3. Diversification. Focus on providing the framework for self- sustaining private and community-based initiatives: investment, technical assistance, business services, adequate infrastructure, education, training, integration of advances in information technology, renewal of villages.}

4. Sustainability. Awareness of responsibility in local actions, promotion of sustainable quality and amenity of rural landscapes (natural resources, biodiversity and cultural identity), so that the options for future generations are not prejudiced.

5. Subsidiarity. As decentralised rural development policy as possible, based on partnership and co-operation between all levels of rural development management.

6. Simplification. Simplification of legislation, rules and procedures and more flexibility overall.

7. Programming. Rural development programmes must be based on coherent and transparent procedures and a single mechanism for sustainable and rural development.

8. Finance. As much financial resources as possible reaching small and medium enterprises, mobilisation of better synergies between public and private funding.

9. Management. Enhancement of the administrative capacity and effectiveness of regional and local governments and communities through the provision of technical assistance, training, better communication, partnership, networking and exchange of experience.

10. Evaluation and Research. Reinforcement of monitoring, evaluation and beneficiary assessment, ensuring transparency, guaranteeing availability of information and proper use of money.
Cork 2.0 Declaration - A Better Life in Rural Areas (2016)*

1. Promoting Rural Prosperity. Adoption and implementation of innovative, sustainable and integrated solutions for current and future societal challenges, development of a multi-sectoral approach, giving value to rural identity and enhancing sustainability, social inclusion and local economy, as well as the resilience of farms and rural communities.

2. Strengthening Rural Value Chains. Developing and strengthening agricultural, forestry and local product value chains and local production networks using integrated methods. The aim is to ensure fair and transparent contractual relations in the supply chain and legal possibilities for farmers to organize collective actions, to provide farmers with effective risk management measures.

3. Investing in Rural Viability and Vitality. All investments have to generate added value to the society, promote employment, green and integrated growth, and sustainable initiatives that foster the competitive and diversified agriculture and rural economy, strengthen the linkages between rural and urban areas and align sustainable development.

4. Preserving the Rural Environment. Land, agricultural and forestry system management in the interface between citizens and the environment, application of measures reflecting the diversity of local circumstances, protection of endangered flora, fauna, local landscapes, development of ecotourism, healthy lifestyle, etc.

5. Managing Natural Resources. Implementation of cutting-edge, science-based, cross-sectoral agricultural management solutions to meet the growing demand for food, feed, fibre and biomass with less natural and other resources.

6. Encouraging Climate Action. Implementation of effective climate change mitigation and adaptation strategies, encouraging farmers and foresters to provide services with a minimal impact on climate change, to produce renewable energy, bio-materials, and to give priority to the circular economy and cascading use of biomaterials.

7. Boosting Knowledge and Innovation. A comprehensive, strong policy focus on social innovation, learning, education, advice and vocational training, development of required skills, strengthening of peer-to-peer exchange, networking and cooperation among farmers and rural entrepreneurs. Training the rural population in the latest scientific innovation and technologies to allow communities, businesses and public authorities operate more closely and apply the latest science and technology achievements.

8. Enhancing Rural Governance. Building on LEADER and the European Innovation Partnership for Agriculture initiatives to mobilize rural potentials through a bottom-up approach; interaction of rural and agricultural policies with the broader context of the national and regional strategies, in line with other policies.

9. Advancing Policy Delivery and Simplification. Further streamlining of the regulatory frameworks of the CAP and further simplification of implementation, development of smart administrative tools and procedures to reduce administrative burdens on beneficiaries and national and regional administrations; implementation of e- governance tools, a simplified cost approach; strengthening subsidiarity and proportionality by sharing fund management and defining control systems.

10. Improving Performance and Accountability. Ensuring transparency, access to information and proper use of funds; implementation of a reliable monitoring and evaluation system involving stakeholders.

*Source: Cork 1.0 Declaration, 1996; Cork 2.0 Declaration 2, 2016. 
All the principles provided for and approved under both Cork declarations guide the stakeholders' decisions towards achieving progress in rural areas. Nevertheless, the principles which were approved under the Cork 2.0 Declaration "A Better Life in Rural Areas" (2016) are more focused on the factors which give rise to, guide and support innovations and strategic breakthroughs in the countryside: circular economy and bio-economy, cascading use of biomaterials, value chains for agriculture and forestry, local produce, and local production networks, etc. There is no doubt that social innovations, close, exchange- and networking-based interaction among industry, researchers, experts, academia, the civic society and the authorities are essential for more efficient use and sharing of the opportunities which have opened up as a result of the scientific and technological progress. Cork 2.0 Declaration recommends developing integrated approaches, complementarity and coherence among different policies.

The "European Action for Smart Villages: For a Brighter Future of Rural Areas in EU" joint conference hosted by the European Commission and the European Parliament in Bled, Slovenia in 2018 resulted in drafting and adoption of the Bled Declaration "Smart Villages". Smart villages are rural areas and communities which offer new opportunities by building on the existing strengths and resources of their respective village. Those are the villages that develop on the basis of traditional and new networks and services by means of digital, telecommunication technologies, innovation, and local and global knowledge (Bled Declaration, 2018). The Declaration acknowledges that, if developed in an integrated, innovative and inclusive way, the rural digital economy is capable of improving the quality of life of rural citizens and thus contributing to tackling the issue of depopulation and migration from rural areas. Smart villages have the potential to enhance economic and social cohesion, to improve the social equality, in particular, between rural and urban areas.

\subsection{The concept of smart villages}

The conceptual background of the article is based on several theoretical approaches: the sustainable development theory, the multi-actor approach, the social partnership theory, the community engagement paradigm and the co-creation process, and the neo-endogenous development concept. Appropriate cooperation towards achieving shared goals is determined by social relations based on voluntary, selfless cooperation and solidarity, prevailing moral unity, as well as responsibility and accountability. In the analysis, rural area development is assumed to include the organizational processes which are a response to the increasingly disappearing agricultural sector, social, economic, spatial inequalities, backwardness, poverty, social exclusion, etc. In other words, the development of rural areas is becoming a response to market failures (Ploeg et al., 2015). According to the neo-endogenous development concept, the development of rural areas is based on the institutional capacity building to ensure mobilization of internal resources and regaining of external forces (Chevalier et al., 2014). Cocreation requires everyone involved to develop empathy, share and accept equal partnership in the creation process. Strategies and methods for involving local communities deeper in cocreation are needed to address these issues (Fleischmann, 2013; Wei Wang et al., 2016). Collaboration between various actors is needed to make the best use of the types of knowledge (scientific, practical, organisational, etc.) in view of co-creation and diffusion of solutions/opportunities ready to be implemented in practice. The value of the community engagement paradigm lies in the potential to engage with a wide range of local community members, to learn about the rural culture, area and sustainability of economic activities, and to share the knowledge in co-creation of cultural and material elements through transdisciplinary activities. The paradigm relies on a deep connection with local activities, the culture of public policy to create publicly engaging activities, which build on the existing traditions and practices (Wei Wang et al., 2016).

The concept of smart villages does not propose a one-size-fits-all solution (Naldi et al., 2015). It is territorially sensitive, based on the needs and the potential of a given territory, and strategyled, supported by a new or existing territorial strategy (Smart Villages in the EU and beyond, 2019). Smart villages can be understood as communities that refuse to simply wait for a change to happen to them. Smart villages are made up of rural people who take the initiative to explore practical solutions to the underlying challenges they face and to seize new opportunities (Holmes, 
2017). Smart villages provide many of the benefits of 21 st Century life to rural communities and reflect a level of rural development consistent with achieving the sustainable development goals (Holmes, 2017). Patel and Shah (2017) analysed Kolavada village in India and defined the components of a smart village: a smart infrastructure, a smart technology and innovation, smart institutions, smart service delivery. This enables smart growth or development. Smart growth strategies can help rural communities achieve their goals for growth and development while maintaining their distinctive rural character. The "smart growth" movement seeks to address these problems in a cost efficient and environmentally friendly manner (Kolbadi et al., 2015). It has numerous benefits: small-scale and partnership-oriented project planning, maintaining, developing and empowering existing applications, development of complex uses, design consistent with the nature, development of public transport, expansion of bike lanes and pedestrian-friendly design, creating balance between the environment and development leading to growth and protection of open spaces and vulnerable nature and water resources. Visvizi and Lytras (2018) defined the conceptual boundaries of a smart village. A village is an ecosystem of a limited size, a community that is driven by specific mechanisms and dynamics that are the product and the outcome of the multi-level interaction among all stakeholders. A smart village is conceptually different from the aggregate construct of a 'rural area' or 'countryside'.

\subsection{Components of the Smart Village model}

In the Smart Cities White Paper, researchers Robledo et al., (2014) defined a smart territory as a living space that is friendly to all types of life with a good-neighbourly and sustainable environment, which represents not only a populated area, but also a reduced negative environmental impact as a result of a more efficient and optimal use of the existing resources, predominately environmentally friendly activities. Smart areas promote the attractiveness of technological solutions that enable identification of a dangerous situation and, if possible, mitigation of the negative effects of the event. These solutions require innovations, knowledge and consciousness of the people involved. Hence, a smart territory covers an urban and rural area as a complex system, where the residents are aware of their resources and how these should be used without affecting the sustainable balance (Robledo et al., 2014). A smart village is made up of people who undertake the initiative to mobilize local resources and assets to tackle the challenges they face, make use of and create the opportunities for rural development. Digital technologies are a powerful tool for smart villages, but not the only one (Bled Declaration, 2018).

According to Baležentis (2011), a village model is a generalized typical version of a village, which represents the most evident reflection of the economic, social, and environmental specifics of the countryside in a country. A Smart Village model defines the means for cultivation of human abilities and helps develop synergy between certain technological achievements. Analysis of scientific literature from various sources disclosed that the list of criteria characterising a smart village is quite long (Table 2) and depends on the village development level.

As mentioned in the literature, smart villages often have more than one element meeting the criteria for classification as smart. It is important to note that various elements of a smart village are interrelated/supplement each other.

Rural communities, stakeholders engaged in farming and other stakeholders in the rural development primarily build on business innovations and focus on the development of new products and processes, address the implementation of new strategies, organisational structures and principles. Progress in agriculture is sought through the formation of a more comprehensive approach, i.e., by combining the following elements in each solution, even though they are often viewed completely separate from each other:

- economic resources (e.g., integration of agriculture and food production, traditional crafts, tourism);

- social resources (e.g., relationship between the producers and consumers);

- environmental resources (e.g., protection of biodiversity, water resources and harvest yield; produce distribution, packaging; reuse of resources);

- cultural resources (e.g., protection of the traditional knowledge) (Marsden, Sonnino, 2008). 
Tab 2. Academic and other sources supporting criteria characterising a smart village. Made by authors

\begin{tabular}{|c|c|c|}
\hline $\begin{array}{l}\text { Smart village } \\
\text { characterising criteria }\end{array}$ & $\begin{array}{l}\text { Frequency } \\
\text { of mention }\end{array}$ & Academic and other sources \\
\hline $\begin{array}{l}\text { Revitalised rural } \\
\text { services }\end{array}$ & 11 & $\begin{array}{l}\text { Edwards, Haines (2007); Naldi et al. (2015); Smarter, Greener, More Inclusive? } \\
\text { (2016); Somwanshi et al. (2016); EU Action for Smart Villages (2017); European } \\
\text { Network for Rural Development (2017); Tirziu, Vrabie (2017); Digital Villages } \\
\text { (2017); Zavratnik et. al. (2018); Sangeetha et al. (2018); Bled Declaration on Smart } \\
\text { villages (2018). }\end{array}$ \\
\hline $\begin{array}{l}\text { Creative economies } \\
\text { and new business } \\
\text { forms }\end{array}$ & 10 & $\begin{array}{l}\text { Naldi et al. (2015); Smarter, Greener, More Inclusive? (2016); Somwanshi et al. } \\
\text { (2016); EU Action for Smart Villages (2017); Smart Countryside study (2017); Tirziu, } \\
\text { Vrabie (2017); Van Gevelt et.al. (2018); Zavratnik et. al. (2018); Sangeetha et al. } \\
\text { (2018); Bled Declaration on Smart villages (2018). }\end{array}$ \\
\hline $\begin{array}{l}\text { Technological, digital } \\
\text { innovation }\end{array}$ & 9 & $\begin{array}{l}\text { Glasmeier, Christopherson (2015); Smarter, Greener, More Inclusive? (2016); EU } \\
\text { Action for Smart Villages (2017); European Network for Rural Development (2017); } \\
\text { Tirziu, Vrabie (2017); Digital Villages (2017); Zavratnik et. al. (2018); Sangeetha et } \\
\text { al. (2018); Bled Declaration on Smart villages (2018). }\end{array}$ \\
\hline $\begin{array}{l}\text { New forms of } \\
\text { partnership }\end{array}$ & \multirow{3}{*}{8} & $\begin{array}{l}\text { Smarter, Greener, More Inclusive? (2016); Smart Countryside study (2017); Tirziu, } \\
\text { Vrabie (2017); Štareikè (2017); Digital Villages (2017); Van Gevelt et.al. (2018); } \\
\text { Sangeetha et al. (2018); Bled Declaration on Smart villages (2018). }\end{array}$ \\
\hline Environment protection & & $\begin{array}{l}\text { Edwards, Haines (2007); Glasmeier, Christopherson (2015); Smarter, Greener, } \\
\text { More Inclusive? (2016); Tirziu, Vrabie (2017); Digital Villages (2017); Zavratnik et. } \\
\text { al. (2018); Sangeetha et al. (2018); Bled Declaration on Smart villages (2018). }\end{array}$ \\
\hline Inclusive community & & $\begin{array}{l}\text { Edwards, Haines (2007); Naldi et al. (2015); Smarter, Greener, More Inclusive? } \\
\text { (2016); EU Action for Smart Villages (2017); Smart Countryside study (2017); } \\
\text { Štareikè (2017); Zavratnik et. al. (2018); Sangeetha et al. (2018); }\end{array}$ \\
\hline Social innovations & \multirow{2}{*}{7} & $\begin{array}{l}\text { Smarter, Greener, More Inclusive? (2016); EU Action for Smart Villages (2017); } \\
\text { European Network for Rural Development (2017); Tirziu, Vrabie (2017); Štareikè } \\
\text { (2017); Zavratnik et. al. (2018); Bled Declaration on Smart villages (2018). }\end{array}$ \\
\hline $\begin{array}{l}\text { Supportive policy } \\
\text { frameworks }\end{array}$ & & $\begin{array}{l}\text { Somwanshi et al. (2016); EU Action for Smart Villages (2017); Smart Countryside } \\
\text { study (2017); Štareikè (2017); Digital Villages (2017); Van Gevelt et.al. (2018); } \\
\text { Sangeetha et al. (2018). }\end{array}$ \\
\hline $\begin{array}{l}\text { Support of local food } \\
\text { chains }\end{array}$ & 5 & $\begin{array}{l}\text { Somwanshi et al. (2016); Orbàn, (2017); Digital Villages (2017); Zavratnik et. al. } \\
\text { (2018); Sangeetha et al. (2018). }\end{array}$ \\
\hline $\begin{array}{l}\text { Natural and } \\
\text { recreational amenities }\end{array}$ & \multirow{2}{*}{4} & $\begin{array}{l}\text { Edwards, Haines (2007); Naldi et al. (2015); Smarter, Greener, More Inclusive? } \\
\text { (2016); Bled Declaration on Smart villages (2018). }\end{array}$ \\
\hline $\begin{array}{l}\text { Energy resource } \\
\text { access innovations }\end{array}$ & & $\begin{array}{l}\text { Smarter, Greener, More Inclusive? (2016); Somwanshi et al. (2016); EU Action for } \\
\text { Smart Villages (2017); Bled Declaration on Smart villages (2018). }\end{array}$ \\
\hline
\end{tabular}

The Smart Village concept reflects a strong linkage among communities, production and consumption methods, and the culture and environment people live in. Such linkage exists when the priority is placed on the local economy. The local economy is strengthened by implementing the principles of sharing, circular economy, and bioresource-based approach. New production and consumption models create conditions for educating people and increasing their awareness about food and environmental protection, deepening producers' knowledge and protecting the distinctive cultural identity. Solutions require innovation, knowledge and consciousness of the people involved. Farmers, residents of rural areas, and employees of the institutions of social infrastructure are the main drivers of progress in the countryside. Integration of diverse knowledge sources and learning forms is one of the key enablers to survival, adaptation, development, and thriving in the countryside and the contemporary agriculture. Researchers (Sumane et al., 2017) note that knowledge from diverse sources may be complementary and optimally combined to develop sustainable solutions, although it may also be contradictory and create obstacles for new ideas and development orientations. Formal (educational, research, consultancy, political) organisations have to collect informal knowledge and acknowledge its value. This acknowledgement would help to make better use of farmers' knowledge and thus to contribute to the development of the knowledge-based society. 


\subsection{Support for institutionalization of social structures in smart villages}

The social structure or social order of rural areas could be treated from the perspective of interactions of established individual and corporate actors. The key question here is what maintains the social structure. Neoinstitutionalists point out that actors establish institutions converting their actions into particular permanent structures of actions and interaction in order to maximize their profits. In order to structure the actions of rural development actors or to ensure the activity of the intuitions, it is necessary to establish appropriate laying down mechanisms.

One of the key open platforms used in the development of smart villages is the Living Labs (European Network of Living Labs, 2018) aimed at engaging consumer communities in innovation of products or services. The Labs provide actual means for identification and testing of consumer needs offered by local public, private and NGO sector partnerships, i.e. by institutions that are open to innovation (Matias, 2018). The authors of the present article consider that local activity groups should contribute to the initiation and development of the Living Lab. These are volunteer organisations established pursuant to the principle of partnership that actively participate in the management of territorial changes. Their management bodies have decision-making powers and represent the interests of the residents of the areas allocated to respective local activity groups, i.e. at least $50 \%$ of the members of the management bodies are representatives of rural communities, social and other partners and associations thereof, up to $25 \%$ of the members are business representatives and up to $25 \%$ of the members are representatives of the local authorities.

The Living Lab paradigm helps create open and interdisciplinary environments. According to the participatory research approach, the stakeholders may accept challenges and create solutions but the focus should be clearly placed on the vision, strong leadership, sustainability of the autonomous character, and a community cultivating a strong sense of challenges and the principles of sustainable development (Guzmán et al., 2013). The solutions are based on research, which usually covers specific local issues and opportunities and, to a certain extent, the human-computer interaction. According to Callaghan and Herselman (2015), the newly created Living Labs have already demonstrated good results in improving collaboration between urban and rural communities, innovations, performance of the industry (bioenergy, environmental protection, in particular), the academia, learners and schools. According to Callaghan and Herselman (2015), the principal values that are followed and those that contribute to the creation of the environment and/or approach include consumers (rural residents, farmers and consumers of their produce and public goods) as the main actors; compulsory inclusion of the local community and various stakeholders; a focus on joint creation and collaboration; aiming at multidisciplinary open innovations; outcomes: improved or new products or processes, which are reproducible and sustainable; effect: social and economic environment (capacity building, development, and empowerment).

The aim of the Smart Rural Living Lab established in 2017 in the rural municipality of Penela, Portugal, is to develop new methodologies and technologies aimed at addressing weaknesses and enhancing strengths of rural areas, defining the course of action for the sustainable rural development, generating local knowledge and exporting the knowledge to other territories, and working with consumers to promote the development of the municipality. Analysis of the experience of the Smart Rural Living Lab has showed that the key challenge addressed by the Lab is the weak local economy. Hence, the main aim of the countryside and the Lab is to strengthen the local economy and to maintain natural resources, to promote citizenship and entrepreneurship, to further prosperity and to improve social development, to promote tourism and preservation of the territorial identity.

The key characteristics of those open innovation platforms include assessment of the rural context as an opportunity to create competitive advantages; a strong territorial approach; development of services and produce that are intended to improve the quality of life in the municipality (Callaghan, Herselman, 2015; Smart Countryside Study, 2017; Digital Villages, 2017). The actions often follow the 4-vector sustainable development model supported by the IT and social infrastructure:

- natural resources (agriculture, fire and climate change prevention, grazing lands, forests); 
- social development and wellbeing (health and elderly people's centres);

- agricultural, tourism and other economic activities and identity (heritage preservation, a virtual hunting and tourism centre);

- citizenship and entrepreneurship (access to the Internet and participation in society) (Tirziu, Vrabie, 2017).

Callaghan and Herselman (2015) identified the key actors who may be interested in the establishment and operation of a Living Lab, such as communities, researchers, public entities, private companies, natural persons, etc. Tirziu and Vrabie (2017) emphasized close relations among the stakeholders and referred to the following stakeholders of a smart village: farmers and business companies capable of obtaining new and innovative ideas; consumers of agricultural and food products and other goods created in the village, who are capable of receiving the desired or required innovation; organisations of public administration and public organisations, which may generate a higher return on investment related to the innovation research; researchers who may be identified and who important information on success stories can be shared with. In the pursuit of mutual interests, the stakeholders create open innovation enabling people to participate in dealing with the challenges of development in their residential area by using networks (knowledge sharing, purchase, co-creation) and knowledge (comprehensive, complementary, including methodological strictness) and receiving the top-down and bottom-up support. In view of the aims, the information collection process includes and promotes the creation of an open database and cultivates the skills in analysis and visualisation. Knowledge generation and trainings go through all project implementation stages.

\section{Research results}

\subsection{Practical usage of sources and driving forces of the smart village development}

In 2018, the focus was placed on the patterns behind the development of smart villages, and researchers, policy makers, and practitioners aimed at identifying and describing the same. Local and international projects already provide clear indications of what should be done to increase the growth of services, jobs and sustainability of the development of rural areas. Since the concept of a "smart village" is gaining a momentum, a number of initiatives have been launched to better understand the drivers behind the "smartness" of a rural area. The authors of the article used the methods of literature analysis, analysis of good practice examples, matching and comparison and identified several practical sources and driving forces in the creation of an environment favourable for the development of smart villages (Table 3). There are major differences in village development practices among countries, "pioneers", who instigate novel activities, and "followers", who apply elements that have already proven their validity.

Analysis of the sources of the manifestation of the smart village development (Smart Countryside Study, 2017; Digital Villages, 2017; Matias, 2018; Social Innovation in Marginalised Rural Areas (SIMRA), 2018, etc.) showed that stakeholders usually focus on universal happiness, meaning similar conditions for everyone in terms of learning, access to health care, leisure, and life ensuring environmentally friendly agriculture and forestry, and enabling every small group of people or community to create its own subtle, individual world.

The authors believe that social innovation and the organisational culture of a rural area play an important role in the smart village model. Analysis of the works by a number of authors (Vveinhardt, 2011; Pikturnaitè, Paužuolienè, 2013; Šimanskienè, Sandu, 2013; Atkočiūnienè et al., 2016; Slivinskienè, 2018), who investigated and assessed organisational culture, show that the organisational culture in the rural area is a self-regulatory mechanism of the local community. It is the entirety of shared values and beliefs of the local community, which transform the stakeholders' attitude and shape their specific behaviour. Moreover, it is a set of governance methods and tools intended to deal with the issues of the rural area development forming the basis for local governance related to the survival in the environment and internal integration, helping to create competitive advantages of the local area, sustainable community, and thus enhancing the viability and resilience of the rural area. 
Tab 3. Sources and driving forces behind the development of smart villages. *

\begin{tabular}{|c|c|c|}
\hline $\begin{array}{l}\text { Sources of the smart } \\
\text { village development } \\
\text { manifestation }\end{array}$ & Main contribution & Driving forces \\
\hline $\begin{array}{l}\text { Case studies and } \\
\text { projects }\end{array}$ & $\begin{array}{l}\text { Innovative strategies and methods in provision } \\
\text { of digital (e-government, e-health, } \\
\text { e- commerce, etc.) and social services, } \\
\text { improved relationships between the } \\
\text { countryside and the city, support to local } \\
\text { actions, integration of various sources of } \\
\text { knowledge and learning modes, tackling } \\
\text { depopulation and digital transition problems. } \\
\text { Projects foster smart areas and they are } \\
\text { particularly beneficial in the fields of education, } \\
\text { research and innovation, and digital society. }\end{array}$ & $\begin{array}{l}\text { Digital and other open platforms for } \\
\text { innovation; rural tourism, including } \\
\text { ecological, healthy food and } \\
\text { recreation, recreational tourism; } \\
\text { social innovation in rural services } \\
\text { and entrepreneurship; development } \\
\text { and implementation of an inclusive } \\
\text { social infrastructure, partnership } \\
\text { organizational mechanism. }\end{array}$ \\
\hline Consultations & $\begin{array}{l}\text { Integrated empowering actions, new business } \\
\text { models, inclusive measures for provision of } \\
\text { rural services, territorial and community } \\
\text { planning, principles of bio-economy, sharing } \\
\text { and circular economy. }\end{array}$ & $\begin{array}{l}\text { A bio-based (renewable) economy; } \\
\text { sharing and circular economy. }\end{array}$ \\
\hline $\begin{array}{l}\text { Reviews of the EU } \\
\text { agriculture and rural } \\
\text { development }\end{array}$ & $\begin{array}{l}\text { Mobilizing the stakeholders into practical } \\
\text { methods of dealing with the challenges faced } \\
\text { by an organisation and provision of local } \\
\text { services, better broadband connectivity and } \\
\text { infrastructure, new win-win relationships with } \\
\text { urban areas and activities, which reinforce } \\
\text { the role of rural areas in the transition to a } \\
\text { greener, healthier and more caring society. }\end{array}$ & $\begin{array}{l}\text { Precise farming (agriculture); } \\
\text { a bio-based (renewable) economy; } \\
\text { renewable energy; social } \\
\text { innovation in rural services and } \\
\text { entrepreneurship. }\end{array}$ \\
\hline $\begin{array}{l}\text { Videos about smart } \\
\text { villages }\end{array}$ & $\begin{array}{l}\text { Integrated solutions, local actions, bio- } \\
\text { resources, information technologies, } \\
\text { technological infrastructure, consistent } \\
\text { acquisition of knowledge and skills by rural } \\
\text { residents, improvement of services in rural } \\
\text { areas. }\end{array}$ & $\begin{array}{l}\text { A bio-based (renewable) economy; } \\
\text { renewable energy; social } \\
\text { innovation in rural services and } \\
\text { entrepreneurship; development and } \\
\text { implementation of an inclusive } \\
\text { social infrastructure. }\end{array}$ \\
\hline Project brochures & $\begin{array}{l}\text { Specialized, highly innovative projects, which } \\
\text { enhance the local identity and use digital, } \\
\text { technological and social innovation aimed at } \\
\text { increasing the quality and supply of rural } \\
\text { services. }\end{array}$ & $\begin{array}{l}\text { Rural tourism, including ecological, } \\
\text { healthy food and recreation, } \\
\text { recreational tourism; sharing } \\
\text { economy; renewable energy; social } \\
\text { innovation in rural services and } \\
\text { entrepreneurship. }\end{array}$ \\
\hline Smart village portals & $\begin{array}{l}\text { Good practice examples of integrated projects, } \\
\text { initiatives and networks, methodological } \\
\text { recommendations, and promotion of } \\
\text { the financial support from all over Europe. }\end{array}$ & $\begin{array}{l}\text { Digital and other open platforms for } \\
\text { innovation. }\end{array}$ \\
\hline
\end{tabular}

*Sources: Smart Countryside Study, 2017; Digital Villages, 2017; Tirziu, Vrabie, 2017; Bled Declaration, 2018, Social Innovation in Marginalised Rural Areas (SIMRA), 2018; Smart Villages: Revitalising Rural Services, 2018. 
Researchers (Wals, 2007; Bettina, 2012; Choi, Majumdar, 2015) and strategic documents (Smarter, Greener, More Inclusive, 2016; EU Action for Smart Villages, 2017) propose different definitions for social innovation. The concept is based not only on analytical and academic but also on the normative concept. In analysing the driving forces behind the development of a smart village, it would be appropriate to follow the three key attributes of social innovation identified by Bettina (2012):

1. Social mechanisms of innovation: the development of the local area and the dissemination and use of innovation always take place simultaneously in the context of the society and they interact with social relationships, real life issues, norms and values.

2. Social responsibility of innovation: it is important to assess the social effect of innovation from the winner and loser perspective. Innovation should be "social", i.e., socially acceptable, meaningful, and morally appropriate. This can be achieved by socialising innovation methods and reorganising innovation as a social and collective learning process to come up with a common definition of the issues and to jointly plan and implement the solutions.

3. Public innovation: the public can use various mechanisms to achieve the unity of its members. That means encouraging reorganisation and improvement of the society, and it is therefore important to know the political elements of social innovation and to analyse which social changes are considered to be desirable and worth the support from the public and authorities.

Examples of social innovation in rural areas usually include improvement of the old, existing activities and processes and strategies, projects and services aimed at meeting the changing needs of rural residents. The areas of social innovation include organisational factors and solutions, social relationships and collaboration networks, which give rise to pro-active changes and are acceptable to the society. The complex, multi-dimensional concept, which contributes to the emergence of new mechanisms, social relationships, and changes, redefines the longestablished norms of behaviour of the locals. Researchers, who are engaged in the international project Social Innovation in Marginalised Rural Areas (SIMRA) (2018), defined social innovation as "reconfiguring of social practices in response to societal challenges, which seeks to enhance the outcomes on societal well-being", and emphasized that social innovation shall cover at least inclusion and participation of the civic society actors. 


\subsection{Case study of Lithuanian smart villages}

In support to the above ideas and with a view of focusing on real experiences of smart villages in Lithuania, it was not by chance that certain villages were chosen as pilot areas for this research. The research methodology part outlines certain criteria for choosing those villages and therefore the researchers found it important to know the characteristics of the pilot rural areas (Table 4).

Tab 4. Characteristics of selected pilot rural areas for the case study of Lithuania. *

\begin{tabular}{|c|c|c|c|c|c|}
\hline Characteristics & Ukrinai & Smalininkai & Naisiai & Vatušiai & Kražiai \\
\hline First mentioned & $\begin{array}{l}\text { The first written data } \\
\text { about the village } \\
\text { date back to the 16th } \\
\text { century. }\end{array}$ & $\begin{array}{l}\text { The first mention in } \\
\text { written sources dates } \\
\text { back to the end of } \\
\text { 15th century. }\end{array}$ & $\begin{array}{l}\text { The first mention of } \\
\text { Naisiai village was in } \\
1658 .\end{array}$ & $\begin{array}{l}\text { Historical sources } \\
\text { mention the village } \\
\text { since } 1554 \text {. }\end{array}$ & $\begin{array}{l}\text { The land of Kražiai } \\
\text { was first mentioned } \\
\text { in } 1253 \text { as Crase. }\end{array}$ \\
\hline $\begin{array}{l}\text { Administrative- } \\
\text { territorial unit }\end{array}$ & $\begin{array}{l}\text { Sub-eldership (the } \\
\text { lowest-level } \\
\text { administrative- } \\
\text { territorial unit } \\
\text { in Lithuania); } \\
\text { Mažeikiai district } \\
\text { municipality } \\
\end{array}$ & $\begin{array}{l}\text { The centre of sub- } \\
\text { eldership; Jurbarkas } \\
\text { district municipality }\end{array}$ & $\begin{array}{l}\text { The centre of sub- } \\
\text { eldership; Šiauliai } \\
\text { district municipality }\end{array}$ & $\begin{array}{l}\text { The centre of sub- } \\
\text { eldership; Rietavas } \\
\text { municipality }\end{array}$ & $\begin{array}{l}\text { The centre of sub- } \\
\text { eldership; Kelmè } \\
\text { district municipality }\end{array}$ \\
\hline Number of residents & $424(2011)$ & $458(2018)$ & $539(2011)$ & $350(2014)$ & $650(2018)$ \\
\hline Geographical features & $\begin{array}{l}\text { It is like a street } \\
\text { village near river } \\
\text { Varduva }\end{array}$ & $\begin{array}{l}\text { Surrounded by lakes } \\
\text { llginys, } \\
\text { Palèkis, } \\
\text { Bildelis. }\end{array}$ & $\begin{array}{l}\text { Located near } \\
\text { Šiauliai, one of the } \\
\text { biggest towns in } \\
\text { Lithuania. }\end{array}$ & $\begin{array}{l}\text { The River Jūra runs } \\
\text { through the village. }\end{array}$ & $\begin{array}{l}\text { The River Kražantè } \\
\text { runs through the } \\
\text { village; the old part } \\
\text { of Kražiai is an } \\
\text { archaeological and } \\
\text { urban monument. }\end{array}$ \\
\hline $\begin{array}{l}\text { Places of interest / } \\
\text { landmarks }\end{array}$ & $\begin{array}{l}\text { Places of cultural } \\
\text { heritage; famous for } \\
\text { stone monuments }\end{array}$ & $\begin{array}{l}\text { Stud farm; tank park; } \\
\text { local port and water } \\
\text { measuring station; } \\
\text { go-cart track }\end{array}$ & $\begin{array}{l}\text { Famous for } \\
\text { educational and } \\
\text { cultural events, } \\
\text { festivals; stud farm; } \\
\text { Baltu Arena; rabbit } \\
\text { island }\end{array}$ & Stud farm & $\begin{array}{l}\text { Famous for } \\
\text { historical, religious } \\
\text { and cultural heritage }\end{array}$ \\
\hline $\begin{array}{l}\text { Green spaces I } \\
\text { approach to the nature }\end{array}$ & \multicolumn{5}{|c|}{ All villages have lots of green spaces (parks, riversides, oak parkways, paths etc.) } \\
\hline \multirow[t]{2}{*}{ Activities } & $\begin{array}{l}\text { Traditional } \\
\text { handicrafts; apple } \\
\text { cheese production } \\
\text { as a part of social } \\
\text { business }\end{array}$ & $\begin{array}{l}\text { Gastronomic / } \\
\text { traditional dishes; } \\
\text { active leisure } \\
\text { activities; use of } \\
\text { renewable energy } \\
\text { sources }\end{array}$ & $\begin{array}{l}\text { Educational, leisure } \\
\text { events }\end{array}$ & $\begin{array}{l}\text { Folk art: oil painting, } \\
\text { colour printing; } \\
\text { gastronomic / } \\
\text { traditional dishes; } \\
\text { participation in "Milk } \\
\text { Road" cluster } \\
\end{array}$ & $\begin{array}{l}\text { Tourism; active } \\
\text { cultural life and } \\
\text { religious events }\end{array}$ \\
\hline & \multicolumn{5}{|c|}{ Traditional, intensive agriculture is typical for all villages } \\
\hline $\begin{array}{l}\text { Role of rural } \\
\text { community }\end{array}$ & \multicolumn{5}{|c|}{ All villages have active rural communities, which perform cultural, social, and environmental functions } \\
\hline
\end{tabular}

Note: Table 4 was made using the same sources as in the Table 5

A parallel drawn between the selected smart village criteria specified in the theoretical part and the information about pilot villages, which was found on the Internet, revealed that not all the theoretical criteria can be adapted to the villages chosen by the authors. The selected villages meet several but nevertheless interrelated criteria specific to smart villages (Table 5). 
Tab 5. Justification of pilot villages' adherence to the smart village criteria in Lithuania. *

\begin{tabular}{|c|c|c|c|c|c|}
\hline $\begin{array}{lll}\text { Criteria } \\
\text { adherence }\end{array}$ & 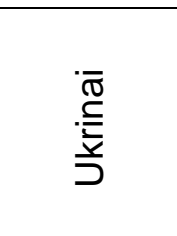 & 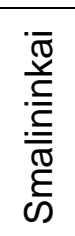 & $\frac{\frac{\bar{\pi}}{\frac{\pi}{N}}}{\frac{\pi}{Z}}$ & $\frac{\bar{\pi}}{\substack{\frac{\pi}{N 0} \\
\frac{\pi}{n}}}$ & $\begin{array}{l}\overline{\bar{N}} \\
\frac{\pi}{N} \\
\bar{N}\end{array}$ \\
\hline 1. Virtual village tour ${ }^{* *}$ & + & + & + & + & + \\
\hline 2. Small cultural capital & $+(2017)$ & & $+(2015)$ & & $\begin{array}{c}+ \\
(2018) \\
\end{array}$ \\
\hline 3. Local food production / support & + & + & & + & \\
\hline 4. Inclusive approach & + & & + & + & \\
\hline \multirow{3}{*}{$\begin{array}{l}\text { 5. Innovation: } \\
\text { 1) Social } \\
\text { 2) Technological, digital } \\
\text { 3) Bioenergy use }\end{array}$} & + & + & + & & \\
\hline & & + & & & \\
\hline & + & + & & & \\
\hline 6. Revitalising rural services & & + & + & + & + \\
\hline $\begin{array}{l}\text { 7. Creative economies and new } \\
\text { business forms }\end{array}$ & + & + & & & \\
\hline 8. Environmental sustainability & + & + & + & & \\
\hline $\begin{array}{l}\text { 9. Partnership / cooperation between } \\
\text { local people / organizations }\end{array}$ & + & & + & + & \\
\hline $\begin{array}{l}\text { 10. Unique natural, cultural and } \\
\text { recreational spaces / objects }\end{array}$ & + & + & + & & + \\
\hline Total: & 10 & 9 & 8 & 5 & 4 \\
\hline
\end{tabular}

*Sources about these villages:

1) Kražiai: Iždonaitè (2012); "Small cultural capital of Lithuania - Kražiai" the final event (in Lithuanian „Mažoji Lietuvos kultūros sostinè 2018 - Kražiai“" baigiamasis renginys: http://www.kraziai.lt/mazojilietuvos-kulturos-sostine-2018-kraziai-baigiamasis-renginys/

2) Naisiai: Sightseeing: http://naisiai.It/lankytini-objektai/; About community: http://naisiai.It/apiebendruomene/

3) Ukrinai: Ukrinai rural community: http://www.mke.It/Ukrin\%C5\%B3_kaimo_bendruomen\%C4\%97; Ukrinai - the Small Cultural Capital of Lithuania, 2017 (in Lithuanian „Ukrinai - 2017 metų mažoji Lietuvos kultūros sostiné“): http://www.santarve.It/aktualijos/ukrinai-2017-metu-mazoji-lietuvos-kulturos-sostine/; Social Business: Illusion turning into Reality in the Countryside (in Lithuanian „Socialinis verslas: iliuzija, virstanti realybe kaime“): https://www.Izinios.It/Ekonomika/socialinis-verslas-iliuzija-virstanti-realybekaime/273819;

4) Smalininkai: Services (in Lithuanian „Paslaugos“): http://smalininkai.It/paslaugos/; (in Lithuanian „Apie ūkị ir bites“: vèjo jėgainès Smalininkuose): https://www.delfi.lt/video/archive/apie-uki-ir-bites-vejo-jegainessmalininkuose-20100731.d?id=62647633

5) Vatušiai: Gastronomy/traditional Samogitian dishes (in Lithuanian „Kulinarija/tradiciniai žemaitiški patiekalai“): http://www.veik.rietave.It/profiliai/organizacijos/vatusiu-bendruomene; Can a small community move big mountains? (in Lithuanian „Ar maža bendruomenè gali didelius kalnus nuversti?"): http://zemaiciolaikrastis.It/13470/ar-maza-bendruomene-gali-didelius-kalnus-nuversti/

**Virtual Tours. Available at: https://www.vietoves.lt/

The performed analysis of the pilot villages demonstrated that some of them meet more criteria than others and among other things reveals areas that are becoming increasingly important to local residents. The analysed sources, which are listed under the table, show that there are high levels of community-driven activity in all the selected villages; however, the authors assume that a lack of skills and managerial competencies prevent the proper development and application of the smart village principles. Four villages attach great importance to rural services aimed at satisfying human needs, and therefore they broaden their choice. Adequately developed and innovative services can ensure that services offered in that area will be used by the local 
community and that, in its turn, has a strong impact on the local economy. A similar situation was observed when the unique natural, cultural and recreational spaces or objects of the selected villages were compared. All the villages have extensive green areas offering cultural, educational and recreational activities. It should be noted those villages are also known on the regional and national level because they have been recognised as small cultural capitals in a particular year. Thanks to this status, they were not only able to promote their village but also to give publicity to the landmarks, interesting activities and people. That was one of the preconditions for a breakthrough in strengthening the status of a smart village, but not the only one. It is interesting to notice that we can find video virtual tours of the above villages on the Internet, which are intended to introduce a relevant area in Lithuania. There are many different initiatives at the rural level: a virtual tour of the village, local food production, small cultural capital activities, etc. The management of initiatives based on the "bottom up" principle enable the rural development actors to solve the internal problems of the village by using relevant methods and tools without leaving the rural area. The pilot villages are still largely dependent on the traditional economic and social activities. Though various types of innovation were seen as a driving force in the analysed villages, it is not always well understood how to implement them in a proper way, and that also affects the state of creative economies and new business forms. Unfortunately, the initiatives are undertaken separately, with little or no coordination at the local and regional level. Rural development actors often lack knowledge, experience, systematic thinking and a proactive approach to local processes, and thus they are not able to adopt innovative rural development solutions. It is, however, not sufficient to focus just on the activity of local organisations, behaviour of the organisations and rural residents, and processes of change, i.e., organisational processes, the content and individual elements thereof. The Cork 2.0 Declaration calls for the development of a rural proofing mechanism, which would systematically review other macro and sectoral policies through a rural lens. The model of the development of a smart village should be based on the functioning of the partnership organisational mechanism defined by Štareikè (2017, p. 12) as "the entirety of information, consultancy, inclusion and participation solutions, otherwise referred to as nods, and of the partnership activities which connect them into chains and operate simultaneously in relation to each other". It is also noteworthy that there is a need for simultaneous action by the stakeholders - inclusion of several activities in the organisational mechanism at one and the same time.

\section{Conclusion and discussion}

Analysis of scientific literature has revealed that experiences of local and international organizations and examples of good practice can help rural development stakeholders understand the basic principles of an advanced rural model including the smart village principles. The research identified driving forces characterizing the most advanced level of rural development: precise farming (agriculture); digital and other open platforms for innovation; sharing economy; a bio-based (renewable) economy; renewable energy; rural tourism, including ecological, healthy food and recreation, recreational tourism; social innovation in rural services and entrepreneurship; development and implementation of an inclusive social infrastructure and partnership organizational mechanism.

The implementation of the smart rural model is based on the bottom-up approach, a responsible and methodical application of the LEADER approach, and a focus on the exchange and integration of formal and informal knowledge by involving all actors in an interactive manner. Knowledge creation and training are organized at all stages of the project implementation.

Evaluation of success cases from the living labs disclosed that rural areas can become more advanced in the deployment of IT, which helps rural communities to develop social innovation and to maintain residential development. Social innovation and the organizational culture of a rural area, which represent a self-regulatory mechanism of the local community, have a particular role in monitoring the adherence to the smart village principles.

Analysis of the pilot rural areas, known as advanced villages, in Lithuania showed that in these areas, there is a potential for innovation. The smart village criteria applied to the pilot areas have revealed that in three out of the five selected villages most of the smart village principles are 
adhered to. The main limitations of smart villages include the lack of technological, digital, energy innovation and human resources. The study confirmed that the village level development initiatives exist with no links to others and with little or no coordination. Consequently, they do not allow for potential synergies and all development benefits.

Research limitations are also related to the fact that, although good practice examples that are known in Lithuania were analysed, the number of villages is rather small. There are almost no official data (statistics, research, reports) about smart villages in Lithuania except for some scientific publications with very basic ideas about this challenging topic. It should be noted that other methods, such as expert interview or observation, could be applied in further stages of this kind of research in order to acquire more knowledge about the existing smart villages in Lithuania.

It appears that the model for smart rural development should be based on the organizational mechanism of partnership, i.e. the functioning of information, consultation, inclusion and participation solutions, multi-activity and multi-stakeholder activities.

\section{Academic references}

[1] Atkočiūnienè, V., Aleksandravičius, A., Dautartè, A., Vitunskienè, V. \& Zemeckis, R. (2016). Ūkiu modernizacija rinku ir kaimo vystymosi kontekste: Lietuvos atvejis. Akademija: Mokslo studija.

[2] Baležentis, A. (2011). Kaimo vietovių raida ir modeliai: darnaus vystymo požiūris Management theory and studies for rural business and infrastructure development. 26(2), 31-38.

[3] Bock, B. B. (2012). Social innovation and sustainability; how to disentangle the buzzword and its application in the field of agriculture and rural development. Studies in Agricultural Economics 114, 57-63. DOI: 10.7896/j.1209.

[4] Callaghan, R. \& Herselman, M. (2015). Applying a Living Lab methodology to support innovation in education at a university in South Africa. TD The Journal for Transdisciplinary Research in Southern Africa, 11(1), 21-38.

[5] Chevalier, P., Mačiulytè, J., Dedeire, M., Prapiestienè, R. \& Razafimahefa, L. (2014). Vietos iniciatyvos ir teritorinis vystymas: LEADER programos igyvendinimas Lietuvoje ir Prancūzijoje. Geografija 50(2), 76-85. DOI: 10.6001/geografija.v50i2.3004.

[6] Choi, N. \& Majumdar, S. (2015). Social Innovation: Towards and a Conceptualisation. In Majumdar, S., Guha, S., Marakkath, N., eds., Technology and Innovation for Social Change, (pp. 7-34). New Delhi: Springer. DOI: 10.1007/978-81-322-2071-8_2.

[7] Darwin, S. \& Chesbrough, H. (2017). Smart farming in Andhr Pradesh, India: an open innovative approach [research paper]. Berkeley: University of California.

[8] Edwards, M. M. \& Haines, A. (2007). Evaluating smart growth: Implications for small communities. J. Plan. Educ. Res. 27, 49-64. DOI: 10.1177/0739456X07305792.

[9] Fleischmann, K. (2013). Social entrepreneurs and social designers: Change makers with a new mindset? International Journal of Business and Social Science, 4(16), 9-17.

[10] Glasmeier, A. \& Christopherson, S. (2015). Thinking about Smart Cities. Cambridge Journal of Regions, Economy and Society 8, 3-12. DOI:10.1093/cjres/rsu034.

[11] Guzmán, J. G., Del Carpio, F. A., Colomo-Palacios, R. \& De Diego, V. M. (2013). Living labs for user-driven innovation: a process reference model. Research-Technology Management, 56(3), 29-39. DOI: 10.5437/08956308X5603087.

[12] Holmes, J. et al. (2017). The Smart Villages Initiative: Findings 2014-2017. Cambridge: Trinity College.

[13] Iždonaitè, S. (2012). Kražiai: nykstantys ar atgyjantys? Istorija, dabartis, perspektyvos. Kaimo raidos kryptys žinių visuomenèje. 3, 156-165. 
[14] Kolbadi, N., Mohammadi, M. \& Namvar, F. (2015). Smart Growth Theory as One of the Main Paradigms of Sustainable City. International Journal of Review in Life Sciences. 5(9), 209 219.

[15] Marsden, T. \& Sonnino, R. (2008). Rural development and the regional state: Denying multifunctional agriculture in the UK. Journal of Rural Studies 24, 422-431. DOI: 10.1016/j.jrurstud.2008.04.001.

[16] Naldi, L., Nilsson, P., Westlund, H. \& Wixe, S. (2015). What is smart rural development? Journal of Rural Studies 40, 90-101. DOI: 10.1016/j.jrurstud.2015.06.006.

[17] Orbàn, A. (2017). Building Smart Communities in the Hungarian Social Economy. Community Development Journal 52, 668-684. DOI: 10.1093/cdj/bsv053.

[18] Patel, B. N. \& Shah, R. (2017). Smart village a case study of Kolavada village. International Research Journal of Engineering and Technology 4(12), 907-911.

[19] Pikturnaitè, I. \& Paužuolienè, J. (2013). Organizacinès kultūros institucionalizavimas Tiltai 4, 93-107.

[20] Ploeg, J. D., Ye, J. \& Schneider, S. (2015). Rural development: actors and practices. Constructing a New Framework for Rural Development Research in Rural Sociology and Development 22, 17-30. DOI: 10.1108/S1057-192220150000022001.

[21] Robledo, J. G., Larios, V. M. \& Gomez, L. (2014). Living Lab for Smart Territory [technical report]. University of Guadalajara. DOI: 10.13140/RG.2.2.24925.67047.

[22] Sangeetha, V., Singh, P., Satyapriya, Lenin, V., Paul, S., Sukanya Barua, Muralikrishnan, L. \& Sitaram. (2018). An Agri-Nutri (A2N) Smart Village Model for Food and Nutrition Security. New Delhi: Indian Agricultural Research Institute.

[23] Slivinskienè, R. (2018). Kaimo vietovės organizacinės kultūros valdymo modelis [Master Thesis]. Akademija: Aleksandro Stulginskio universitetas.

[24] Somwanshi, R., Shindepatil, U., Tule, D., Mankar, A. \& Ingle, N. (2016). Study and development of village as a smart village. International Journal of Scientific \& Engineering Research, 7(6), 395-408.

[25] Sumane, S., Kunda, I., Knickel, K., Strauss, A., Tisenkopfs, T., Des los Rios, I., Rivera, M., Chebach, T. \& Ashkenazy, A. (2017). Local and Farmers' Knowledge Matters! How Integrating Informal and Formal Knowledge Enhances Sustainable and Resilient. Agriculture, Journal of Rural Studies, 59, 232-241. DOI: 10.1016/j.jurstud.2017.01.020.

[26] Šimanskienè, L. \& Sandu, L. (2013). Organizacinès kultūros vertinimo metodai. Regional Formation and Development Studies 10(2), 201-210. DOI: 10.15181/rfds.v10i2.155.

[27] Štareikè, E. (2017). The phenomenon of the partnership organisational mechanism in a local action group [Doctoral dissertation]. Akademija: Aleksandro Stulginskio universitetas.

[28] Van Gevelt, T., Canales Holzeis, C., Fennell, S., Heap, B., Holmes, J., Hurley Depret, M., Jones, B. \& Safdar, M. T. (2018). Achieving universal energy access and rural development through smart villages. Energy for Sustainable Development 43, 139-142. DOI: 10.1016/j.esd.2018.01.005.

[29] Wang, W., Bryan-Kinns, N. \& Ji, T. (2016). Using Community Engagement to Drive CoCreation in Rural China. International Journal of Design, 10(1), 37-52.

[30] Vidickienè, D., Gedminaitè-Raudonè, Ž. \& Vilkè, R. (2016). Idealaus poindustrinès gyvenvietès modelio paieškos: ekokaimu atvejis. In 7-oji moksliné-praktiné konferencija „Lietuvos kaimo vietoviu konkurencingumo stiprinimas: geroji patirtis” (pp. 58-62). Akademija: Aleksandro Stulginskio universitetas.

[31] Visvizi, A. \& Lytras, M. D. (2018). It's Not a Fad: Smart Cities and Smart Villages Research in European and Global Contexts. Sustainability 10, 2727. DOI: 10.3390/su10082727. 
[32] Visvizi, A., Lytras, D. M. \& Mudry, G., eds. (2019). Smart villages in the EU and beyond. Bingley: Emerald Publishing.

[33] Vveinhardt, J. (2011). Organizacijos kultūros ir organizacinès kultūros charakteristikos Management theory and studies for rural business and infrastructure development. 29(5), 221-230.

[34] Wals, A. E. J. (2007). Social learning towards a sustainable world. Principles, perspectives, and praxis. Wageningen Academic Publishers. DOI: 10.3920/978-90-8686-594-9.

[35] Zavratnik, V., Kos, A. \& Stojmenova Duh, E. (2018). Smart Villages: Comprehensive Review of Initiatives and Practices. Sustainability. 10, 2559. DOI:10.3390/su10072559.

\section{Other sources}

[36] A Better Life in Rural Areas. Cork 2.0 Declaration (2016). Brussel: European Commission.

[37] A Living Countryside. Cork Declaration (1996). Brussel: European Commission.

[38] Digital Villages. Germany (2017). Brussel: European Network for Rural Development.

[39] EU Action for Smart Villages (2017). Brussel: The European Commission.

[40] European Network of Living Labs. Brussel. Available from https://enoll.org/.

[41] Guidance for Local Actors on Community-Led Local Development (2018). European Structural and Investment Funds, Brussel: European Commission.

[42] Matias, L. (2018). Smart Rural: Inspiring Innovation in The Rural World. New Innovation Concept. [a presentation]. Available from http://www.reseau-

pwdr.be/sites/default/files/SmartRural-apresent18_ENG_wallon.compressed.pdf.

[43] Smart Countryside study. Finland (2017). Brussel: European Network for Rural Development.

[44] Smarter, Greener, More Inclusive? (2017). Luxembourg: Publications Office of the European Union.

[45] Smart Villages. Bled Declaration for a Smarter Future of the Rural Areas in EU.

[46] Smart Villages. Revitalising rural services through social and digital innovation (2017). Brussel: European Network for Rural Development.

[47] Smart Villages Revitalising Rural Services (2018). Brussel: European Network for Rural Development.

[48] Social Innovation in Marginalised Rural Areas (2018). Available from http://www.simrah2020.eu/index.php/2018/02/23/.

[49] The Future of Food and Farming. Communication From The Commission To The European Parliament, The Council, The European Economic And Social Committee And The Committee Of The Regions. Brussel: European Commission.

[50] The New Rural Paradigm: Policies and Governance (2006). Paris: OECD.

[51] Tirziu, A. M. \& Vrabie, C. (2017). Living Labs - Instruments of Social Innovation in Rural Areas. In Proceedings of the Central and Eastern European e/Dem and e/Gov (CEEEGov) Days 2017.

[52] Transformimg our World: the 2030 Agenda for Sustainable Development (2015). New York: United Nations. 